\title{
The capital structure of Chinese listed firms: is manufacturing industry special?
}

\author{
Author 1* \\ Address \\ Email: xx@ $\mathbf{x x}$
}

Author 2

Address

Email: xx@xx

* Corresponding author 


\title{
The capital structure of Chinese listed firms: Is manufacturing industry special?
}

\begin{abstract}
Purpose - This paper examines whether or not industry membership can explain the leverage of Shanghai listed firms prior to the 2007 financial crisis. In view of the central role that the manufacturing industry played in China's rise as a global economic power, we are particularly interested in whether or not manufacturing is a special case.
\end{abstract}

Design/methodology/approach - The paper undertakes a comparative study of leverage differences between manufacturing and non-manufacturing industry firms on a cross-section and time-series basis. This is supplemented by a regression analysis that models the factors determining leverage on an industry-by-industry basis.

Findings - We find that leverage levels differ across industries because of industry-based differences in financial characteristics. It is also found that, despite playing a leading role in China's economic development, there is no evidence to suggest that manufacturing is a special case. Across all sectors borrowing-power-related variables were identified to be important determinants of leverage and, contrary to our expectations, factors relating to profitability were largely insignificant.

Research limitations/implications - The Trade Off and Pecking Order capital structure theories found to be commonly applicable to firms in the in the Western business environment do not appear to adequately explain capital structure in China.

Originality/value - We identify evidence to suggest that China needs to be treated as a 'special case' in the context of capital structure theory due to the unique cultural and business environment.

Keywords Capital Structure, Chinese listed companies, Manufacturing industry, Cultural factors

Paper type Research Paper 


\section{Introduction, literature and hypotheses}

It is not clear how relevant established Western capital structure theories are to Chinese capital markets. For example, Tse and Rodgers (2011) demonstrate that the Tax Shield capital structure model did not apply in the Chinese context. Other Western based research suggests that industry membership can explain between-industry variations of leverage (For example, Tse (2002) in relation to the UK). This paper examines whether or not this is also the case for Shanghai listed companies given the cultural and institutional differences between China and Western countries.

\subsection{Behavioural, Cultural and Institutional influences on capital structure}

Evidence in the literature suggests that capital structure can be influenced by behavioural factors. For example, Bertrand and Schoar (2003) found that financially aggressive CEOs showed a tendency to use higher leverage than their more conservative peers. A number of other studies also indicate that over optimism bias can be a significant issue; Hackbarth (2008) found that over confident managers tend to issue more debt and are less likely to follow a standard pecking order. From a cultural perspective Chui et al. (2002) argue that a nation's culture can affect corporate capital structures. Their cross-country study found that countries with high degrees of cultural 'conservatism' tend to have lower corporate debt ratios. This is particularly important in China where the interests of the individual are seen as relatively less important than those of the group. The importance of cultural factors in China was highlighted by Kai Li et al. (2011) who report that national culture has significant explanatory power in the financial leverage decisions of foreign joint ventures. Chui et al. (2002) conclude by asking if national culture is the missing part of the capital structure puzzle and ask whether this is related to attitudes to saving. A conservative attitude to savings appears to be a Pan-Chinese phenomenon and not just restricted 
to the Peoples Republic of China (PRC). Tung and Baumann (2009) found that Chinese who were born and raised overseas had similar attitudes in this respect to their counterparts in the PRC.

Institutional factors may also possibly influence capital structures. A key distinguishing feature of Chinese capital markets in this respect is the high proportion of listed company shares held by the state. Wei and Geng (2008) argue that this reduces the effectiveness of corporate governance. The overall impact of state ownership on capital structures is however disputed in the literature. Liu et al. (2011) argue that state-owned enterprises (SOE) have higher leverage ratios than their non-SOEs peers and are also more market driven. However, Tse and Rodgers (2011) argue that tax incentive effects mean that the impact of government share holdings on capital structure is unclear as increasing corporate borrowing will reduce government tax revenue through tax shield effects. Huang and Song (2011) on the other hand argue that state ownership has no significant influence on capital structure decision in Chinese firms.

\subsection{Pecking Order and Trade-Off theories of Capital Structure}

These are the two principle (and competing) capital structure theories found in the Western literature. Pecking Order Theory (POT) argues that firms have clear preferences in their sources of funding. Internal funds are normally identified as being at the top of the pecking order and, as a consequence, a negative relationship is predicted between leverage and profitability (more profitable firms will undertake less external borrowing). There is a debate in the literature as to the precise structure of the pecking order. Myers and Majluf (1984) argue that new debt finance will be preferred to equity as new equity can be taken as a signal by investors that managers 
believe the firm's equity to be overvalued. However, Lien et al. (2012) found evidence of a reverse pecking order in China; firms were found to prefer to issue shares rather than debt.

Trade Off theory argues that firms will determine their capital structures by trading off the costs and benefits associated with different sources of finance. For example, long term debt use is determined by the trade-off between the risk of possible bankruptcy and the tax savings associated with debt finance. Jensen and Meckling (1976) and Jensen (1986) extended the model to incorporate the agency cost problem and subsequently Baker et al. (2007) argued that debt financing is a potential agency cost control mechanism as it reduces free cash flow and encourages the monitoring of management by debt providers.

\subsection{Industry membership and capital structure in the literature}

The mix of debt-to-equity has been found to differ from industry-to-industry (Kim, 1997) and also from country-to-country (Wald, 1999). Country based differences may possibly reflect differences in tax regimes if firms are adjusting their leverage to optimise tax shield benefits. To take advantage of tax shields firms need to have good earnings potential and tangible assets to back up any borrowing. These two associated elements are commonly called debt capacity. A study of Chinese firms by Cai et al. (2008) suggested that, although long term debt was small and accounted for only $23 \%$ of total debt, the availability of collateralized assets did have a significant influence on the debt maturity profile.

A number of other studies argue that both industry-related and country-related factors can explain differences in leverage levels. For example, Remmers et al. (1974) found that industryrelated factors were significant in Japan and France but not in the United States (US), the Netherlands and Norway. A subsequent study by Sekely and Collins (1988), that examined 677 
firms in 9 industries across 23 countries, argued that country level effects are possibly more important than industry level effects. They put these differences down to cultural influences. More recently Jong et al. (2008) also reported country-related influences on firms' leverage levels and MacKay and Phillips (2005) argue that, in the US at least, financial structures are determined at firm level rather than industry level.

Although the literature in respect to industry-based leverage effects is somewhat equivocal, we argue in this paper that if Western capital structure models are applicable to Chinese firms we would expect to find some evidence of industry-based leverage effects. The literature in respect to the impact of China's rapid economic growth on capital structures is very limited. In particular, we can find no substantive research that attempts to examine industry-related differences in these capital structures. This issue is of particular interest given that the evidence suggests China may eventually become the biggest economy in the world.

Any industry-based leverage effects could, we argue, potentially be a function of the level of debt capacity. Woodruff (2007), using US data covering 2001-2005, identified debt capacity as being potentially a function of four factors: the proportion of property and plant and equipment in total assets, industry group (because of asset specificity), sales variability and the depreciation method used. He found the first two factors to be statistically significant in explaining the debt capacity. Higher debt capacity was particularly pronounced in respect to the (non-high technology) manufacturing industry. This is possibly not surprising as firms in this industry produce similar products and services and also utilize assets that have similar asset specificity risk (Espahbodi et al., 2002). 
The principal conceptual argument of this paper is that growing industries with high levels of tangible assets (for use as collateral) and with high levels of profit growth will borrow more. Therefore, we would expect there to be substantial differences in leverage-related financing behaviour between manufacturers and other industries.

\subsection{Hypotheses and contributions}

Following our review of literature presented above, we establish the following testable hypotheses:

1. Amongst profitable Chinese listed companies leverage is industry dependent;

2. Leverage will be significantly higher in the manufacturing industry;

3. Industry-based differences in leverage can be explained in terms debt capacity (borrowing power and profitability) differences ${ }^{\mathrm{i}}$.

Using a market competition based perspective Guney et al. (2011) found some evidence to suggest that industry factors may affect Chinese firms borrowing level. We, however, examine this issue from a debt capacity perspective. This paper contributes to the literature as follows:

1. By examining the extent to which capital structure decisions are industry-dependent for Shanghai stock market listed firms. A particular focus is placed on the manufacturing industry given its preeminent role in driving Chinese economic development. We examine whether or not it is a 'special case' in terms of the ways in which it uses leverage given its need to raise large amounts of new capital.

2. By identifying innovative variables that are arguably better proxies for 'borrowing power' than those found in the current literature. We identify two groups of explanatory variables which, 
we argue, are highly industry-dependent and use these in a direct test of the industry membership hypothesis. We argue that this approach is novel in the context of the literature. Previous tests of industry membership theory, for example Talberge et al. (2008), rely on general capital structure models rather than developing a direct test.

3. By presenting evidence that profitability related factors are not important influences on leverage levels in Chinese firms. This calls into question whether or not both Pecking Order and Trade-Off theories can be applied to Chinese firms. We argue that this surprising finding may relate to Chinese cultural factors; specifically, that the negative attitude of the Chinese towards borrowing at personal level appears also to be reflected in corporate culture.

The paper is structured as follows: Section 2 describes the dataset and our sampling procedures. Section 3 is a cross section and time series comparative study of leverage differences in manufacturing and non-manufacturing industries. Section 4 uses regression analysis to model the factors determining leverage on an industry-by-industry basis. Section 5 discusses whether or not China is a special case in the context of capital structure theory and finally Section 6 concludes the paper.

\section{Data Description}

Our sample is drawn from Shanghai Stock Exchange 'A' share index as at November $25^{\text {th }} 2008$. The principal source is the Reuters 3000 Xtra global financial database. At this time there were 852 companies that had been listed on a continuous basis from 2002 to 2007. After excluding 21 finance industry companies, this left an initial sample of 831 . The data, shown on an industry 
basis, is summarised in Table 1. Data was not used beyond 2007 in order to avoid potential complications associated with global financial crisis and to maintain a relatively 'normalised' data set corresponding to a relatively stable economic environment ${ }^{\mathrm{ii}}$.

The data set was further adjusted to include only firms that used long term debt finance and were also in a position to make adjustments to their leverage ratios. For example, a significant number of companies with negative equity that were financed predominantly through their current liabilities are excluded from the sample. The omission of a large number of cases would normally indicate that potential sample selection bias issues would need to be examined as part of any statistical procedures. However, in this study this issue does not arise as the analysis being undertaken is conditional on the cases in the sample having the potential to make significant adjustments to long-term debt.

Based on the criteria identified above we exclude firms that: had negative pre-tax profits, that historically have made no use of long-term debt (LTD) finance, that had negative equity, that had annual EBIT growth exhibiting excessive volatility (growth changes by 10 fold or more) and finally some obvious outliers where current liabilities exceed half of total liabilities and interest paid is more than LTD. The final exclusion is more data related; the sample omits firms where it is likely that a significant part of the interest paid related to short-term borrowing costs. This approach is taken because the data-set used does not enable the identification of separate shortterm loan and long-term loan interest payments. This means that where there are significant short-term loans, the use of such data would introduce a significant upwards bias in estimates of long-term borrowing costs. This problem cannot be eliminated, but to minimize it we omit firms with high current liabilities relative to total liabilities as they are likely to have significant short term loans (such as bank loans). We assume that if these firms were also paying large interest 
payments relative to their LTD, then a substantial proportion of these payments are unlikely to relate to the LTD.

\subsection{Preliminary analysis of the data}

Given China's export orientation, manufacturing companies dominate market listings in terms of firm numbers; they represent $55 \%$ of the initial sample shown in Table 1 . The next biggest industry group is I.T. services representing around 6.6\%. The test-sample dataset shown in the second column is reasonably representative; for example, manufactures and I.T. services account for $53 \%$ and $5.1 \%$ respectively. It can be noted that there was significant between-industry variation in average firm size, as measured by total assets. The mining/oil industry stands out in this respect. 


\section{Table 1: Companies listed on Shanghai ' $A$ ' stock exchange on a continuous basis 2002-2007 shown by industry}

\begin{tabular}{lllllll}
\hline Industry & $\begin{array}{l}\text { Total } \\
\text { listed }^{\mathbf{a}}\end{array}$ & $\begin{array}{l}\text { Test } \\
\text { Sample }\end{array}$ & Average size $^{\mathbf{b}}$ & $\begin{array}{l}\text { Mean debt } \\
\text { borrowing } \\
\text { capacity }\end{array}$ & St. deviation $^{\mathbf{c}}$ & T-test $^{\mathbf{d}}$ \\
\hline Total & 831 & 550 & 15.25 & 0.48 & 0.23 & - \\
Manufacturing & 461 & 292 & 4.84 & 0.45 & 0.19 & - \\
Agriculture & 24 & 15 & 1.98 & 0.42 & 0.11 & -1.24 \\
Conglomerates & 44 & 25 & 8.43 & 0.50 & 0.22 & 1.46 \\
Construction & 41 & 19 & 14.13 & 0.32 & 0.21 & $-3.83^{* * *}$ \\
Utilities & 39 & 34 & 15.84 & 0.76 & 0.13 & $13.7^{* * *}$ \\
I.T. & 55 & 28 & 5.05 & 0.30 & 0.16 & $-6.43^{* * *}$ \\
Mining/Oil & 19 & 18 & 101.1 & 0.56 & 0.15 & $3.10^{* * *}$ \\
Real Estate & 29 & 24 & 7.73 & 0.23 & 0.24 & $-4.84^{* * *}$ \\
Wholesale/Retail & 43 & 36 & 3.73 & 0.50 & 0.25 & 1.28 \\
Others & 76 & 59 & 2.83 & 0.65 & 0.22 & $7.48^{* * *}$
\end{tabular}

Notes: a As at November $25^{\text {th }} 2008$; ${ }^{\text {b }}$ Average size of sample companies measured by Total Assets (shown in units of 1 billion Yuan and sourced from financial statements for 2007); ${ }^{\mathrm{T} T F A}$ /TA sourced from financial statements for 2007; whilst there is no generally accepted definition of debt borrowing capacity identifiable in the literature, the measurement used here can be viewed as a proxy. Total Fixed assets exclude intangibles; ${ }^{\mathrm{d} C o m p a r i s o n-o f-m e a n s ~ T-t e s t ~ c o m p a r i n g ~ m a n u f a c t u r i n g ~ i n d u s t r y ~}$ debt borrowing capacity against other industries.

Table 1 identifies large industry-related differences in estimated mean debt borrowing capacity ${ }^{\text {iii }}$. We use T-tests to test the significance of the mean-differences between manufacturing and other industries. The statistical significance found suggests that borrowing capacity variation may be industry-based and therefore any industry-based leverage differences may have a common cause. We plot a graph, Figure 1, which gives an indication that, with the possible expectation of two industries, Real Estates and Construction, there appears to be a positive relationship between borrowing capacity and leverage. 


\section{Figure 1: Average Debt Capacity vs. Average Leverage for 2007 in selected industries ${ }^{\text {a }}$}

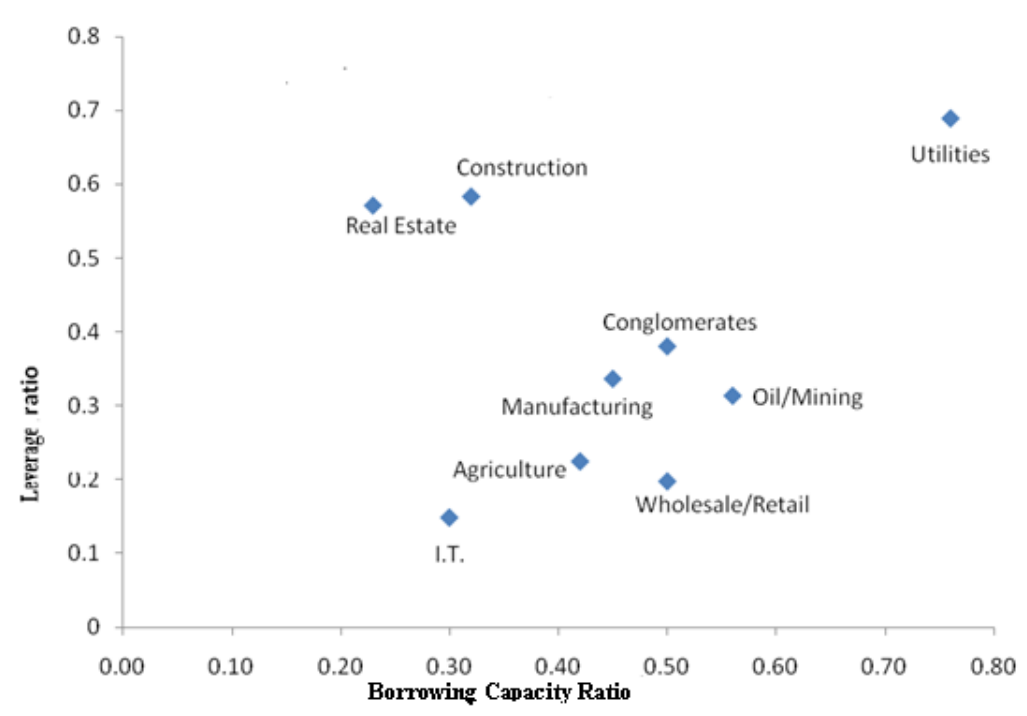

Notes: astimates derived from Tables 1 and 2a

\section{Hypotheses 1 and 2: results and analysis}

A series of F-statistic based comparison-of-means hypothesis tests are undertaken to identify whether or not leverage levels found in the 'base case' of manufacturing firms are statistically significantly different from those of other industries. From these we hope to be able to identify whether or not manufacturing is a 'special case' as per Hypothesis 2. These same tests will also provide evidence as to whether or not there is evidence to support Hypothesis 1.

With Chinese economic growth being in the region of $10 \%$ per year over the period in question (2002-2007) the financial structures and profitability rates of the sample-set of companies were relatively volatility. Therefore in order to ensure the robustness of our analysis we examine leverage levels on a year-by-year basis and, in addition for comparative purposes, use two different definitions of leverage. We believe that survivor bias is not an issue in our time-series analysis as, despite the rapid rate of economic growth, the de-listing of a company is a rare event 
in China ${ }^{\text {iv }}$. It can also be noted from Tables 2 and 3 that the individual industry samples do not show large year-on-year variation.

Although the manufacturing industry did not show the highest average debt borrowing capacity in Table 1, the mean EBIT levels were high relative to average firm size and the EBIT standard deviation was relatively low ${ }^{v}$. It might be expected that this, combined with lower perceived default risk resulting from the fact that the Chinese economic boom has been based mainly on the manufacturing industry, may have potentially made borrowing easier for manufacturers relative to other industries. We would therefore expect that Chinese manufacturing firms should borrow significantly more than, for example, construction and real estate, where there is substantially lower borrowing capacity.

Tables 2 and 3 report the results from a series leverage comparison tests undertaken on a yearby-year basis over the period 2002-2007. The two tables are based on two alternative measures of the leverage widely found in the empirical literature (LTD/E and LTD/TA). This approach is taken so that comparisons can be made for robustness. It can be noted that in the empirical literature a number of different definitions of the numerator are found. For example, De Miguel and Pindado (2001) use market value whilst Titman and Wessels (1988) use book value. We argue that the use of market value is inappropriate for this particular study because any tax shield effect of borrowing is determined by the amount of interest payable on the debt and not the market value.

Hypothesis 1 postulates that leverage levels are industry dependant. It can be seen from Tables 2 and 3 that there is considerable variation in leverage between industries; Table 2a shows that in 2007 leverage ranges between 0.69 (utilities industry) and 0.15 (I.T. industry). The statistical significance of the difference between the 'base case' manufacturing industry and some of the 
other industry groups provides some support for our first hypothesis (this is not conclusive as we undertake no formal significance test in respect to other industry base case groups). An examination of the changes in mean leverage over time indicates marginal increases across most industries. It can also be noted that there is evidence of greater leverage volatility in some individual industries. It is possibly a little surprising that the trend towards increasing leverage has not been greater given the need for increasing capital in a rapidly expanding economy has been accompanied by increases in levels of Chinese debt issuance (Hale, 2007).

Table 2a:

\section{A comparison of manufacturing company mean leverage ratios with other industries (leverage: Long-Term Debt/Shareholder Equity)}

The mean leverage ratio of manufacturing industry companies is compared against those of companies from other industries over the period 2002-2007. The F-values relate to comparison-of-mean tests where the degrees of freedom use the Satterthwaite approximation ${ }^{\mathrm{a}}$.

The mean manufacturing leverage ratio is higher than that of other industries in half of the cases. This is not related to debt capacity as, for example, construction and real estate have a lower debt capacity than manufacturing. The statistical significance of the industry-related differences found was limited. This partly reflects wide withinindustry leverage variations within some industries.

\begin{tabular}{|c|c|c|c|c|c|c|c|c|c|}
\hline \multirow[t]{2}{*}{ Industry } & \multicolumn{3}{|l|}{2007} & \multicolumn{3}{|l|}{2006} & \multicolumn{3}{|l|}{2005} \\
\hline & Sample & $\begin{array}{l}\text { Mean } \\
\text { leverage }\end{array}$ & F-value & Sample & $\begin{array}{l}\text { Mean } \\
\text { leverage }\end{array}$ & F-value & Sample & $\begin{array}{l}\text { Mean } \\
\text { Leverage }\end{array}$ & F-value \\
\hline Manufacturing & 292 & 0.337 & & 282 & 0.308 & & 268 & 0.338 & \\
\hline Agriculture & 15 & 0.225 & 1.769 & 12 & 0.154 & 2.440 & 10 & 0.187 & $5.426 * *$ \\
\hline Conglomerates & 25 & 0.382 & 0.109 & 28 & 0.331 & 0.075 & 24 & 0.609 & 1.473 \\
\hline Construction & 19 & 0.584 & 2.622 & 18 & 0.491 & 1.871 & 17 & 0.492 & 0.422 \\
\hline Utilities & 34 & 0.690 & $5.471 * *$ & 33 & 0.769 & $9.622 * * *$ & 32 & 0.652 & $4.607 * *$ \\
\hline IT & 28 & 0.149 & $9.811 * * *$ & 25 & 0.163 & $3.406 *$ & 20 & 0.131 & $16.071 * * *$ \\
\hline Mining/Oil & 18 & 0.314 & 0.048 & 17 & 0.219 & 0.048 & 16 & 0.463 & 0.500 \\
\hline Real Estate & 24 & 0.573 & $3.940 *$ & 18 & 0.573 & $3.521 *$ & 15 & 0.498 & 2.276 \\
\hline Wholesale/Retail & 36 & 0.198 & $7.629 * *$ & 26 & 0.258 & $7.629 * *$ & 33 & 0.199 & $3.036 *$ \\
\hline
\end{tabular}

Notes: ***Significant at 1\%; **Significant at 5\%; *Significant at 10\%; ${ }^{\text {a }} d f=\left[\left(\left(s^{2}{ }_{1}+s_{2}\right)^{2}\right) /\left(\left(\left[\left(s_{1}^{2}\right) /\left(n_{1}-1\right)\right]+\left[\left(s_{2}{ }^{2}\right) /\left(n_{2}-1\right)\right]\right)\right)\right]$ 
Table 2b:

\section{A comparison of manufacturing company mean leverage ratios with other industries (leverage: Long-Term Debt/Shareholder Equity)}

The mean leverage ratio of manufacturing industry companies is compared against those of companies from other industries over the period 2002-2007. The F-values relate to comparison-of-mean tests where the degrees of freedom use the Satterthwaite approximation ${ }^{\mathrm{a}}$.

It can be noted that leverage is trending upwards over time. This is especially apparent in industries such as utilities which increase from 0.34 in 2002 to 0.69 in 2007.

\begin{tabular}{|c|c|c|c|c|c|c|c|c|c|}
\hline \multirow[t]{2}{*}{ Industry } & \multicolumn{3}{|l|}{2004} & \multicolumn{3}{|l|}{2003} & \multicolumn{3}{|l|}{2002} \\
\hline & Sample & $\begin{array}{l}\text { Mean } \\
\text { leverage }\end{array}$ & F-value & Sample & $\begin{array}{l}\text { Mean } \\
\text { leverage }\end{array}$ & F-value & Sample & $\begin{array}{l}\text { Mean } \\
\text { Leverage }\end{array}$ & F-value \\
\hline Manufacturing & 303 & 0.295 & & 313 & 0.252 & & 287 & 0.228 & \\
\hline Agriculture & 11 & 0.211 & 2.067 & 19 & 0.270 & 0.032 & 18 & 0.194 & 0.274 \\
\hline Conglomerates & 30 & 0.389 & 0.676 & 33 & 0.364 & 0.789 & 27 & 0.125 & $11.036 * * *$ \\
\hline Construction & 16 & 0.339 & 0.137 & 14 & 0.257 & 0.004 & 13 & 0.369 & 3.132 \\
\hline Utilities & 33 & 0.596 & $9.017 * * *$ & 32 & 0.522 & $9.537 * * *$ & 33 & 0.335 & $3.505 *$ \\
\hline IT & 23 & 0.176 & $2.891^{*}$ & 26 & 0.260 & 0.005 & 31 & 0.179 & 0.352 \\
\hline Mining/Oil & 18 & 0.375 & 0.507 & 16 & 0.358 & 0.700 & 12 & 0.281 & 0.204 \\
\hline Real Estate & 14 & 0.502 & 1.494 & 15 & 0.285 & 0.184 & 13 & 0.316 & 0.574 \\
\hline Wholesale/Retail & 36 & 0.248 & 0.624 & 37 & 0.299 & 0.151 & 39 & 0.225 & 0.001 \\
\hline
\end{tabular}

Notes: ***Significant at $1 \%$; *Significant at 10\%; a $d f=\left[\left(\left(s^{2}{ }_{l}+s_{2}\right)^{2}\right) /\left(\left(\left[\left(s_{1}{ }^{2}\right) /\left(n_{1}-1\right)\right]+\left[\left(s_{2}{ }^{2}\right) /\left(n_{2}-1\right)\right]\right)\right)\right]$ 


\section{Table 3a:}

\section{A comparison of manufacturing company mean leverage ratios with other industries (leverage: Long-Term Debt/Total Assets)}

The mean leverage ratio of manufacturing industry companies is compared against those of companies from other industries over the period 2002-2007. The F-values are estimated as in Table 2.

The absolute measures of leverage are significantly different from Table 2 estimates. However, there is little difference in the relative leverage of manufacturing and other industries indicating that the results of the modelling procedures are robust from the perspective of leverage definition. In comparison with Table 2, the statistical significance of between-industry differences exhibits greater consistency over time. This probably reflects this measure being less sensitive to changes in the value of the denominator.

\begin{tabular}{|c|c|c|c|c|c|c|c|c|c|}
\hline \multirow[t]{2}{*}{ Industry } & \multicolumn{3}{|l|}{2007} & \multicolumn{3}{|l|}{2006} & \multicolumn{3}{|l|}{2005} \\
\hline & Sample & $\begin{array}{l}\text { Mean } \\
\text { leverage }\end{array}$ & F-value & Sample & $\begin{array}{l}\text { Mean } \\
\text { leverage }\end{array}$ & F-value & Sample & $\begin{array}{l}\text { Mean } \\
\text { Leverage }\end{array}$ & F-value \\
\hline Manufacturing & 292 & 0.109 & & 282 & 0.100 & & 268 & 0.104 & \\
\hline Agriculture & 15 & 0.086 & 0.095 & 12 & 0.051 & $4.159^{*}$ & 10 & 0.077 & 2.043 \\
\hline Conglomerates & 25 & 0.113 & 0.026 & 28 & 0.103 & 0.022 & 24 & 0.081 & 1.843 \\
\hline Construction & 19 & 0.101 & 0.070 & 18 & 0.104 & 0.016 & 17 & 0.106 & 0.007 \\
\hline Utilities & 34 & 0.190 & $8.099 * * *$ & 33 & 0.204 & $11.804 * * *$ & 32 & 0.219 & $13.381 * * *$ \\
\hline IT & 28 & 0.048 & $15.711 * * *$ & 25 & 0.046 & $18.172 * * *$ & 20 & 0.054 & $9.823 * * *$ \\
\hline Mining/Oil & 18 & 0.126 & 0.327 & 17 & 0.101 & 0.003 & 16 & 0.126 & 0.776 \\
\hline Real Estate & 24 & 0.172 & $6.371 * *$ & 18 & 0.175 & $4.810^{* *}$ & 15 & 0.139 & $4.312 * *$ \\
\hline Wholesale/Retail & 36 & 0.067 & $6.850 * *$ & 26 & 0.074 & $2.823 *$ & 33 & 0.050 & $17.370 * * *$ \\
\hline
\end{tabular}

Notes: ***Significant at $1 \% ; * *$ Significant at $5 \% ; *$ Significant at $10 \%$. 
Table 3b:

\section{A comparison of manufacturing company mean leverage ratios with other industries (leverage: Long-Term Debt/Total Assets)}

The mean leverage ratio of manufacturing industry companies is compared against those of companies from other industries over the period 2002-2007. The F-values are estimated as in Table 2.

\begin{tabular}{|c|c|c|c|c|c|c|c|c|c|}
\hline \multirow[t]{2}{*}{ Industry } & \multicolumn{3}{|l|}{2004} & \multicolumn{3}{|l|}{2003} & \multicolumn{3}{|l|}{2002} \\
\hline & Sample & $\begin{array}{l}\text { Mean } \\
\text { leverage }\end{array}$ & F-value & Sample & $\begin{array}{l}\text { Mean } \\
\text { leverage }\end{array}$ & F-value & Sample & $\begin{array}{l}\text { Mean } \\
\text { Leverage }\end{array}$ & F-value \\
\hline Manufacturing & 303 & 0.104 & & 313 & 0.098 & & 287 & 0.092 & \\
\hline Agriculture & 11 & 0.093 & 0.288 & 19 & 0.099 & 0.001 & 18 & 0.086 & 0.044 \\
\hline Conglomerates & 30 & 0.113 & 0.120 & 33 & 0.105 & 0.078 & 27 & 0.053 & $11.988 * * *$ \\
\hline Construction & 16 & 0.113 & 0.065 & 14 & 0.076 & 0.985 & 13 & 0.100 & 0.231 \\
\hline Utilities & 33 & 0.213 & $18.473 * * *$ & 32 & 0.207 & $18.639 * * *$ & 33 & 0.161 & $8.111 * * *$ \\
\hline IT & 23 & 0.057 & $6.485 * * *$ & 26 & 0.071 & 1.225 & 31 & 0.052 & $4.928 * *$ \\
\hline Mining/Oil & 18 & 0.139 & 1.421 & 16 & 0.144 & 1.661 & 12 & 0.134 & 0.708 \\
\hline Real Estate & 14 & 0.142 & 2.061 & 15 & 0.127 & 0.714 & 13 & 0.126 & 0.870 \\
\hline Wholesale/Retail & 36 & 0.074 & $6.333 * *$ & 37 & 0.074 & $2.760 *$ & 39 & 0.059 & $3.983^{*}$ \\
\hline
\end{tabular}

Although the borrowing capacity estimates in Table 1 and the leverage estimates in Tables 2 and 3 are not fully comparable (due to small sampling differences) inferences can be drawn on an indicative basis. Table 1 identifies utilities as showing high levels of borrowing capacity and from Tables 2 and 3 we can observe that this industry also shows the highest leverage ratios. Reference to Figure 1 also suggests a generally positive relationship between leverage and borrowing capacity. However, rather surprisingly low borrowing capacity industries such as construction and real estate exhibit relatively high levels of leverage (Figure 1 and Table 2). These two industries appear the only clear exceptions to the positive relationship between borrowing capacity and leverage level.

Do manufacturing firms have significant higher leverage because they are the economic growth engine in China? Tables 2 and 3 would suggest not as they indicate that there are a 
number of industries where the mean leverage level was consistently higher than manufacturing. These were: conglomerates, construction, utilities and real estate.

Although some caution is needed in interpreting these results given the relative small sample sizes in some industries, we believe that the results provide substantive evidence to the effect that no support can be found for Hypothesis 2; I.e. we do not find that leverage levels are higher in manufacturing vis-a-vis other industries.

It should be noted that the F-test results show only the utilities industry and to a lesser extent the I.T. industry to have leverage levels that are statistically significantly different from manufacturing on a consistent basis over time. The general lack of significance may possibly be partly a reflection of the small sample in respect to some industries. The lower levels of significance in Table 2 may also be partly because leverage measured in terms of LTD/E is sensitive to changes in measured equity. So, for example, a fall in equity value can result a significant increase in leverage even when there is no change in borrowing.

In summary, the results provide some evidence in support of Hypothesis 1; namely, that variation in the leverage levels of profitable debt-issuing Chinese listed companies is industry dependent. However, Hypothesis 2 is rejected. To explore these issues further more robust evidence is required as to why industry membership matters in determining leverage. This is investigated in the next section with a regression-based study. 


\section{Hypothesis 3: methodology, results and analysis}

\subsection{Methodology and model}

Regression models using between-industry data can be run using pooled data if heterogeneity is not pervasive. Poolability F-tests undertaken on a cross-sectional basis indicated that the data was not poolable. This is not surprising given the between-industry differences in size and borrowing capacity identified in the dataset.

We argue that the within-industry samples used in this $\mathrm{d}$ study are likely to be more homogeneous than the between-industry samples given the dataset characteristics. It can be noted from the 'Test Sample' dataset in Table 1 that for most industries the standard deviation of listed company debt borrowing capacity is low relative to their industry means.

The data can be pooled on a time basis only if time-related heterogeneity is not pervasive given that heterogeneity can lead to bias (Pesaran and Smith, 1995). In order for this approach to be tenable the efficiency gains from pooling need to be shown to more than offset bias associated with any heterogeneity within the dataset. Tests presented In Table 4 confirm that, with the possible exception of the construction and wholesale/retail industries, the data is poolable over time.

The methodology employed is to pool the within-industry data on a time basis and to run the same regression model across each industry. A series of parameter comparison tests (Clogg et al. 1992) are then undertaken and the results of these are reported in Table 5. These tests identify whether or not there are statistically significant between-industry differences in the parameter values of the explanatory variables. The existence of significant differences would imply that 
industry membership does matter in terms of what impact an individual variable has on leverage. We would argue that this approach can have advantages over a panel based methodology. Baltagi et al. (2000) for example, argue that even panel estimators with heterogeneous coefficients are generally inferior in forecasting performance compared to pooled estimators.

The variables used in the leverage regression models are as follows:

Dependent variable:

Where:

$$
y_{i t}=\frac{L T D_{i t}}{T A_{i t}}
$$

LTD Long-Term Debt

TA Total Assets

We considered both definitions used in Tables 2 and 3. Our preferred measure reflects the greater parameter stability found in using this definition for estimates in Table 3.

\section{Independent variables:}

The independent variables used fall into two principal categories that, we argue, are industrydependent determinants of debt capacity. The first group relate to factors influencing borrowing power. The second group relate to profitability.

Borrowing Power related variables:

Size [Dummy variable which $=1$ where total assets are over 15 billion Yuan, which is the mean for listed firms in 2007; expected positive relationship]. 
This variable takes into consideration the relatively under-developed nature of the Shanghai bond market which will make it relatively more difficult for smaller companies to raise funds through the issuing of debt. We would expect larger companies to have greater access to the market.

Listed [Number of years the company has been listed; expected relationship positive].

It might be expected that companies with a relatively short track record may find raising debt finance more difficult.

BorrowCap $=\frac{T F A_{i t}}{T A_{i t}} \quad$ [Borrowing capacity (or in less formal terms-borrowing power); Tangible Fixed Assets/ Total Assets; expected relationship positive]

This variable measures the proportion of assets that can be implicitly considered as collateral assets.

Profitability related variables

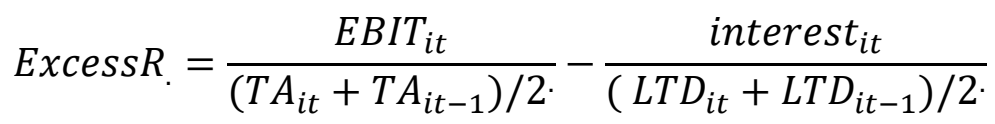

[Difference between investment return and borrowing costs; expected relationship positive ${ }^{\mathrm{vi}}$ ]. 
It will only make commercial sense to borrow if average investment returns exceed average borrowing costs. The expectation is that the greater the difference then the greater incentive to borrow.

P. Ability $=\frac{\left(E B I T_{i t}+E B I T_{i t-1}\right) / 2}{T A_{i t}}$

[Two year average EBIT /Total Assets; expected relationship positive].

This variable measures the profitability of a firm relative to total assets. Volatility is partly smoothed by measuring profitability in terms of the two year average EBIT.

ProfitG $=\frac{E B I T_{i t}-E B I T_{i t-1}}{E B I T_{i t-1}}$

[Earnings growth rate; expected relationship positive].

Potential leverage will depend not only on absolute profitability but also on the rate of profit growth. This is because a rapid rate of growth is an indication to a potential bond investor of company stability and lower financial risk.

Volatility $=\frac{\text { Standard Deviation EBIT } 2002-2007}{\text { Mean EBIT }}$

[Earnings volatility; expected negative relationship] 
The final profitability dimension in the model relates to earnings volatility. The measure used is the coefficient of variation for EBIT from the period 2002-2007.

\subsection{Results}

The results of the regression analysis are presented in Table 4 below. The 'Total' model, shown in Column 1, identifies that across the Shanghai market as a whole the borrowing power related variables show greater statistical significance than the profitability related variables. The firm Size, number of years Listed and the potential borrowing capacity (BorrowCap) are all significant at the $1 \%$ level. It can be noted however that the sign on Listed is contrary to initial expectations. Of the profitability related variables only the difference between investment returns and borrowing costs (ExcessR) is significant in the 'Total' model. A caveat that can be added is that this variable is itself only found to be significant in respect to two individual industries.

If the individual industry models are examined in more detail what appears to stand out is that BorrowCap is both consistently positive and highly significant across all industries except wholesale/retail. The parameter values do however vary from industry to industry which suggests there are industry-related differences in the ways in which the capacity effect impacts on borrowing behaviour.

The other two borrowing power related variables show considerable more industry-related variability in terms of parameter size, sign and significance. This indicates that their relationship with leverage is not consistent across industries. It can be noted that the Size parameter is significant in some industries but not in others and it is also negative in relation to mining/oil. In respect to Listing, the parameter values also show variations between industries in relation to 
both the significance and the sign. The negative relationship found in the manufacturing industry may possibly indicate that in a fast growing industry being an established firm with a known 'history' is not important and could in fact be seen to have negative connotations by investors/lenders looking for new ventures and future potential.

Table 4a: Time-pooled regression results by industry for companies listed on a continuous basis 2002-2007. Dependent variable $=$ LTD/TA

\begin{tabular}{|c|c|c|c|c|c|c|}
\hline & Total & Manufacturing & Agriculture $^{\mathrm{a}}$ & Conglomerates & Construction & Utilities \\
\hline Constant & $0.03099 * * *$ & 0.00167 & $0.05802^{*}$ & $0.04858^{*}$ & -0.02028 & $-0.13386^{*}$ \\
\hline Size & $0.06072 * * *$ & $0.04181 * * *$ & & $0.22547 * * *$ & 0.00893 & $0.06169 * *$ \\
\hline Listed & $-0.00180 * * *$ & $-0.00165^{* * *}$ & $-0.00611^{*}$ & 0.00069 & $0.00858^{* * *}$ & -0.00198 \\
\hline BorrowCap & $0.17479 * * *$ & $0.21776 * * *$ & $0.11600 * *$ & $0.08053 * *$ & $0.21967 * * *$ & $0.45633 * * *$ \\
\hline ExcessR & $0.00001 * * *$ & $0.00001 * *$ & 0.00002 & $0.00003 * *$ & -0.00001 & -0.00004 \\
\hline P.Ability & -0.00811 & -0.00095 & -0.01816 & -0.01651 & -0.02957 & $-0.16142 * *$ \\
\hline Profit G & 0.00121 & 0.00142 & 0.0066 & 0.00266 & 0.00056 & 0.00050 \\
\hline Volatility & 0.00034 & 0.00016 & 0.00194 & -0.00012 & 0.00830 & $0.00460 *$ \\
\hline $\begin{array}{l}\text { Poolability } \\
\text { Test }^{\text {b }}\end{array}$ & 1.309 & 1.273 & 1.272 & 1.475 & $2.882 *$ & 1.674 \\
\hline sample & 2681 & 1491 & 72 & 125 & 85 & 179 \\
\hline Adj- $R^{2}$ & 0.194 & 0.192 & 0.146 & 0.294 & 0.252 & 0.2814 \\
\hline
\end{tabular}

Notes: The top 3 explanatory variables in italics relate to borrowing power with the remainder being profitability-related factors;

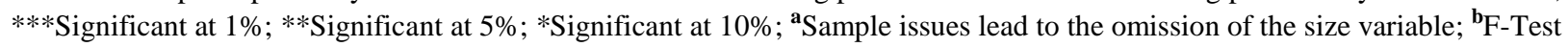
for Poolability over time; Rejection of the null hypothesis indicates data is not poolable; Differences in sample sizes mean that the critical value varies between industries. $F_{o b s}=\frac{\left(S S E_{\left.\text {pooled }-\sum S S E_{\text {year }}\right) /(T-1) K}\right.}{\sum S E E_{\text {year }} / T(n-K)}, d f=F_{(T-1) K, T(n-k)}$; Where $\mathrm{T}=$ number of firms, $\mathrm{K}=$ number of model parameters. 
Table 4b: Time-pooled regression results by industry for companies listed on a continuous basis 2002-2007. Dependent variable $=\mathrm{LTD} / \mathrm{TA}$

\begin{tabular}{llllll} 
& IT & Mining/Oil & Real Estate & Wholesale/Retail & Others \\
\hline Constant & 0.01297 & 0.05916 & $0.13978^{* * *}$ & $0.05541^{* * *}$ & -0.00397 \\
Size & 0.01044 & $-0.04741^{*}$ & 0.04951 & 0.00233 & $0.07311^{* * *}$ \\
Listed & -0.00082 & $-0.01007^{* *}$ & 0.00205 & -0.00029 & -0.00020 \\
BorrowCap & $0.13595^{* * *}$ & $0.25881^{* * *}$ & $-0.14913^{* *}$ & 0.01862 & $0.21986^{* * *}$ \\
& & & & & \\
ExcessR & 0.00001 & -0.00002 & 0.00001 & 0.00001 & 0.00002 \\
P.Ability & -0.02834 & $-0.32606^{* * *}$ & -0.1029 & -0.00671 & -0.00498 \\
Profit G & 0.00042 & 0.01553 & 0.00583 & $0.00954^{* *}$ & -0.00565 \\
Volatility & 0.00140 & $-0.03780^{* *}$ & $0.02336^{* *}$ & 0.0031 & 0.00166 \\
& & & & & \\
Poolability & 2.068 & 1.74 & 2.378 & $\mathrm{a}$ & 1.973 \\
test & & & & & \\
Sample & 107 & 87 & 90 & 162 & 283 \\
Adj- R $\mathbf{R}^{2}$ & 0.214 & 0.119 & 0.080 & 0.016 & 0.169
\end{tabular}

Notes: See Table 4a in respect to tests undertaken; ainsufficient observations in some variables to compute test over the full period.

Our third hypothesis postulates that industry related differences in leverage can be explained in terms of debt capacity (borrowing power and profitability) differences. From Table 4 it can be noted that the borrowing power variables are largely significant and of the expected sign. The influence of profitability however is limited; only ExcessR is both of the expected sign and significant in both the market as a whole and manufacturing.

Table 4 does not consider whether or not borrowing power and profitability factors can explain differences in leverage between industries. We examine this issue in Table 5 which explores whether or not the values of individual industry parameters show statistically significantly differences from the manufacturing 'base case'. We apply the Clogg et al. (1992) test for equality of regression parameter coefficients; this test is conditional on the application of the same regression model for both data groups. 
Table 5 reveals statistically significant industry-related differences for most variables. For example, in respect to BorrowCap, significant differences from the manufacturing 'base case' are found in respect to 5 of the 8 industries tested. It can also be noted that there is no consistency in respect to the signs of these differences; 4 signs are negative and 4 signs are positive. These findings indicate to us that even though debt capacity appears to influence the level of leverage (Table 4), the between-industry differences in parameter values shows us that these variables cannot be used to explain why leverage is higher or lower in one industry in comparison with another. We therefore reject Hypothesis 3 and conclude that industry membership does matter. Even though borrowing capacity and profitability are important variables they have been found to affect different industries in different ways. In effect there is no 'one size fits all' debt capacity focused capital structure model that can be applied across different Chinese industries.

We would argue that our research provides additional tentative evidence to question the relevance of both Pecking Order Theory and Trade Off Theory in the Chinese context. The former suggests there should be a negative relationship between leverage and profitability (assuming that profitability is cash generating) and the latter suggests that we should find a positive relationship (as profitable firms need to borrow more to enjoy tax shield benefits). We argue that the lack of consistency between industries in both the sign and significance of the profitability-related variables in Table 4 indicates that neither theory can be used with confidence to explain the industry-based differences found in China. Our result can be contrasted with other studies made in an emerging market context. For example, Sheikh and Wang (2011) found evidence to suggest that capital structure in Pakistan was consistent with both Trade-off Theory 
and Pecking order Theory. A further study by Al-Narrar and Taylor (2008) argues that in Jordan firms follow the same determinants of capital structure as developed markets.

\section{Table 5: Statistical significance ${ }^{a}$ of industry-related parameter differences relative to the manufacturing industry}

\begin{tabular}{|c|c|c|c|c|c|c|c|c|}
\hline & Conglomerate & Construction & Utilities & I.T. & Mining/oil & Real estate & $\begin{array}{l}\text { Wholesale/ } \\
\text { retail }\end{array}$ & Others \\
\hline Constant & $1.653^{*}$ & -0.809 & $-1.964 * *$ & 0.689 & 1.221 & $5.196 * * *$ & $2.954 * * *$ & -0.171 \\
\hline Size & $3.973 * * *$ & -0.910 & 0.698 & -1.227 & $-2.965 * * *$ & 0.159 & -0.845 & 1.266 \\
\hline Listed & 1.047 & $3.915 * * *$ & -0.134 & 0.549 & $-2.147 * *$ & 1.471 & 0.894 & 0.646 \\
\hline BorrowCap & $-3.287 * * *$ & 0.031 & $2.674 * * *$ & $-2.421 * *$ & 0.509 & $-5.469 * * *$ & $-7.491 * * *$ & 0.054 \\
\hline ExcessR & 0.006 & -0.002 & -0.004 & 0.000 & -0.001 & 0.001 & 0.001 & 0.004 \\
\hline P.Ability & $-2.027 * *$ & $-2.410 * *$ & $-20.427 * * *$ & $-3.522 * * *$ & $-16.851 * * *$ & $-8.663 * * * *$ & -0.721 & -0.427 \\
\hline Profit G & 0.040 & -0.008 & -0.013 & -0.033 & 0.131 & 0.018 & 0.077 & -0.347 \\
\hline Volatility & -1.167 & $33.917 * * *$ & $18.500 * * *$ & $5.167 * * *$ & $-158.167 * * *$ & $96.667 * * *$ & $12.250 * * *$ & $6.250 * * *$ \\
\hline
\end{tabular}

Notes: The top 3 explanatory variables shown in italics relate to borrowing power with the remainder relating to profitability; Agriculture is excluded from the tests as the pooled regression omits the size variable due to insufficient data; ***Significant at $1 \%$;

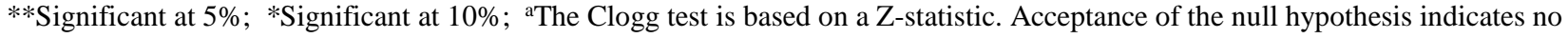
difference between the means

$Z=\frac{\beta_{1}-\beta_{2}}{\sqrt{S E \beta_{1}^{2}+S E \beta_{2}^{2}}}$

Table 5 above also provide additional support for Hypothesis 1; our finding of statistically significantly between-industry differences in respect to the impact of debt capacity factors on leverage indicates that variations in leverage will be industry dependent. The results also provide additional evidence against Hypothesis 2 as it can be inferred that there appear to be no clear and unequivocal systematic differences between the manufacturing industry and other industries in terms of the ways in which the explanatory variables influence leverage. 


\section{Is China a 'special case' in the context of capital structure?}

We list some of our thoughts on the reasons why the leverage levels of profitable Chinese listed companies differ to those in Western countries and therefore why China may need to be considered as a 'special case' in the context of capital structure theory.

\section{Relatively underdeveloped corporate bond markets}

It has been well documented that there is a propensity for Chinese firms use short-term bank borrowing in preference to long-term debt (Hale, 2007). The reason for this may just be that the corporate bond market has not developed to a degree that enables listed companies to issue the debt needed to create optimal capital structures.

The need to promote the development of the corporate bond market is acknowledged by the Chinese monetary authorities. For example, the governor of the Peoples bank of China in 2005 stated: "China's underdeveloped corporate bond market has distorted the financing structure in the economy, which poses a threat to financial stability, as well as to social and economic development." (Zhou, 2006). He went on to list a series of mistakes committed during the late 1980s and mid-1990s that had impeded the development of the market. These ranged from a lack of a credit rating system to the targeting of retail rather than institutional investors and also a lack of investor education. It may possibly be the case in the long run that as the corporate debt market develops Western capital structure models will become more applicable to Chinese firms. However, there may also be cultural issues that place limits on such development. 


\section{Cultural factors}

Cultural factors were identified by Sekely and Collins (1988) as having a significant influence on industry-related leverage differences between countries. It might be expected that the cultural aversion to borrowing found in Chinese society might in part explain why lower leverage levels are found in Chinese listed companies than in their developed country peers (Hale, 2007).

The Chinese in general do not like to borrow. The tendency to save and not borrow was highlighted by Zhou when he was the governor of the People's Bank of China ${ }^{\text {vii }}$. He identified that China's 2007 domestic savings rate of almost half of gross domestic product was far too high $^{\text {viii }}$ and indicated that it was a function of social and cultural factors. He said: “... change ... may be a slow process, especially when you want to change national traditions, cultural impacts, family structures and demographics". It is difficult to say with confidence that the behaviour and attitudes of a country's individuals to saving and borrowing will also be reflected in attitudes and behaviour at the company level. However, we believe that using such a hypothesis to explain of the unwillingness of Chinese firms to use higher leverage merits further investigation.

\section{Individual firm factors}

There are a number of papers suggesting that firm factors, or within-industry-effects, can have a significant impact on leverage; for example, MacKay and Phillips (2005). Other papers can be cited that have found substantial between-industry differences in the amount of within-industry leverage variability; for example, Almazan and Molina (2005). Care needs to be taken in the interpretation of such studies. It is arguable that their findings could possibly reflect outliers in their data. In our study, as discussed above, sampling procedures have been careful to eliminate outliers. 


\section{Conclusions and suggested future research}

This paper examines whether or not leverage differences found between Chinese listed firms prior to the 2007 financial crisis were industry related. It also examines whether or not the 'engine' of Chinese economic development, namely the manufacturing industry, was a 'special case' in respect to leverage. It is found that leverage was not generally higher in the manufacturing industry; in fact it was lower than in some other industries. It was also identified that industry membership did matter when it came to what determined leverage levels. Detailed analysis based on industry-by-industry regression found that firms' leverage levels in China were largely industry dependent and determined more by borrowing power than by profitability. The lack of a significant profitability effect is surprising but possibly reflects the uncertainty surrounding profit growth rates in what was (and still is) a very rapidly expanding economy. We also concluded that manufacturing industry cannot be considered as unique or a 'special case' in any way. Leverage levels were not found to be significantly higher, and in respect to the variables that determine leverage, there did not seem to be any clear and unequivocal differences compared to other industries.

Another important finding was that between-industry leverage differences could not be explained by either borrowing-capacity-related factors or profitability-related factors. We speculate that this may be because of business environment issues; for example, that the development of the Chinese corporate bond market had been relatively slow and that leverage levels were low for Chinese listed firms compared to their Western counterparts. It may also be that that this lack of significance partly related to cultural environment issues; specifically the widespread aversion in China to debt and borrowing. It remains to be seen whether or not with the passage of time the factors which influence leverage levels in the West will become more 
influential in China as well. The period covered by this study can be identified as being one of rapid economic growth where a generally benign financial environment led to increases in profitability and relatively low levels of perceived borrowing risk. It may very well be that in less rosy economic times borrowing will become harder as a significant economic slow-down would affect both the ability and the willingness of fiscally cautious firms to borrow. We also must not lose sight of the fact that China economically is still an emerging nation where financial markets such as the corporate debt market are still nothing like as developed as those found in the West. It is therefore very difficult to predict the future shape of capital structure in China. An interesting follow-up study might be to examine if the same relationships still hold in 10 years time. 


\section{References}

Almazan, A., and Molina, C. (2005), "Intra-Industry Capital Structure Dispersion", Journal of Economics and Management Strategy, Vol. 14, pp. 263-297.

Al-Najjar, B. and Taylor, P., (2008), "The relationship between capital structure and ownership structure: New evidence from Jordanian panel data", Managerial Finance, Vol. 34, pp. 919-933.

Bertrand, M., and Schoar, A. (2003), "Managing with style: The effect of managers on firm policies”, Quarterly Journal of Economics, Vol.118: pp. 1169-1208.

Baltagi, B.H., Griffin J.M. and Xiong, W. (2000), "To pool or not to pool: Homogeneous versus heterogeneous estimators applied to cigarette demand", Review of Economics and Statistics, Vol. 82, pp. 117-26.

Baker, H.K., Saadi, S., Dutta, S. and Gandhi, D. (2007), "The perception of dividends by Canadian managers: new survey evidence", International Journal of Managerial Finance, Vol. 3: pp. 70-91.

Cai, K., Fairchild, R. and Guney, Y. (2008), "Debt maturity structure of Chinese companies", Pacific-Basin Finance Journal, Vol. 16: pp. 268-297.

Chui A.C.W., Lloyd, A.E. and Kwok, C. C. Y. (2002), "The Determination of Capital Structure: Is National Culture a Missing Piece to the Puzzle", Journal of International Business Studies, Vol. 33, pp. 99-127.

Clogg, C., Petkova, E. and Shihadeh, E.S. (1992), "Statistical methods for analyzing collapsibility in regression models", Journal of Educational Statistics, Vol.17, pp. 51-74.

De Miguel, A. and Pindado K. (2001), "Determinants of capital structure: new evidence from Spanish panel data", Journal of Corporate Finance, Vol. 7, pp. 77-99.

Espahbodi, H., Espahbodi, P., Rezaee, Z. and Tehranian, H. (2002), "Stock price reaction and value relevance of recognition versus disclosure: the case of stock-based compensation", Journal of Accounting and Economics, Vol. 33, pp. 43-73.

Guney, Y., Li, L. and Fairchild, R. (2011), "The relationship between product market competition and capital structure in Chinese listed firms", International Review of Financial Analysis, Vol. 20: pp. 41-51.

Hale, G. (2007), "Prospects for China's Corporate Bond Market", Federal Reserve Bank of San Francisco Economic Letter 2007-07.

Hackbarth , D. (2008), "Managerial Traits and Capital Structure Decisions", Journal of Financial and Quantitative Analysis, Vol. 43, pp. 843-882. 
Huang, G., and Song, F.M. (2006), "The Determinants of Capital Structure: evidence from China", China Economic Review, Vol. 17, pp. 14-36.

Jensen, M.C., and Meckling, W.H. (1976), "Theory of the firm: managerial behavior, agency costs and ownership structure", Journal of Financial Economics, Vol. 3, pp. 305-60.

Jensen, M.C. (1986), "Agency cost of free cash flow, corporate finance and takeovers", American Economics Review, Vol. 76, pp. 323-339.

Jong, A., Kabir, R. and Nguyen, T. (2008), "Capital structure around the world: the role of firmand country-specific determinants", Journal of Banking and Finance, Vol. 32, pp. 1954-1969.

Kai Li, K., Griffin. D., Yue, H. and Zhao, L. (2011), "The Determination of Capital Structure: Is National Culture a Missing Piece to the Puzzle?", Journal of International Business Studies, Vol. 42, pp. 477-503.

Lien, D., Lo, M. and Ni, J. (2012), "Selective asymmetric capital financing behaviour: preference towards equity financing", Annals of Financial Economics, available from: www.worldscientific.com (accessed 10/31/12).

Liu, Q., Tian, G. and Wang, X. (2011), "The effect of ownership structure on leverage decision: new evidence from Chinese listed firms", Journal of Asia Pacific Economy, Vol. 16, pp. 254276.

Kim W.G. (1997), "The determinants of capital structure choice in the US restaurant industry", Tourism Economics, Vol. 3, pp. 329-340.

MacKay, P. and Phillips, G. (2005), "How does industry affect firm financial structure?", The Review of Financial Studies, Vol.18, pp. 1433-1466.

Myers, S.C. and Majluf, N.S. (1984), "Corporate financing and investment decisions when firms have information that investors do not have", Journal of Financial Economics, Vol. 13, pp. 187221.

Pesaran, M.H. and Smith, R. (1995), "Estimating long-run relationships from dynamic heterogenous panels", Journal of Econometrics, Vol. 68, pp. 79-113.

Remmers, L., Stonehill, A., Wright, R. and Beekhuisen T. (1974), "Industry and size as debt ratio determinants in manufacturing internationally", Financial Management, Vol. 3, pp. 24-32.

Sekely, W. and Collins, J. (1988), "Cultural influences on international capital structure", Journal of International Business Studies, Vol. 19, pp. 87-100. 
Sheikh, N.A. and Wang, Z. (2011), "Determinants of capital structure: An empirical study of firms in manufacturing industry of Pakistan", Managerial Finance, Vol. 37, pp.117-133.

Talberge, M., Winge, C., Frydenberg, S. and Westgaard, S. (2008), "Capital structure across industries", International Journal of the Economics of Business, Vol. 15, pp. 181-200.

Titman, S., and Wessels, R. (1988), "The determinants of capital structure choice", Journal of Finance, Vol. XUII, pp. 1-19.

Tse, C.B. (2002), “Top Gearing”, Financial Management, Chartered Institute of Management Accountants, pp.36-37.

Tse, C.B., and Rodgers, T. (2011), "Can corporate tax shields explain the long-term borrowing behaviour of Chinese listed firms?", International Review of Financial Analysis, Vol. 20, pp. 103-112.

Tung, R.L., and Baumann, C. (2009), "Comparing the attitudes toward money, material possessions and savings of overseas Chinese vis-a-vis Chinese in China: convergence, divergence or cross-vergence, vis-a-vis 'one size fits all' human resource management policies and practices", International Journal of Human Resources Management, Vol. 20, pp. 2382-2401.

Wald, J. (1999), "How firm characteristics affect capital structure: an international comparison", Journal of Financial Research, Vol. 22, pp. 161-187.

Wei, G. and Geng, M. (2008) "Ownership structure and corporate governance in China: some current issues", Managerial Finance, Vol. 34, pp. $934-952$.

Woodruff, S. (2007), "Factors explaining debt capacity", Management Research News, Vol. 30, pp. 240-251.

Zhou, X. (2006), "China's corporate bond market development: lessons learned", BIS Papers No. 26: Developing corporate bond markets in Asia, Basle: Bank for International Settlements. 
${ }^{i}$ Differences in leverage may be also potentially be explained by: agency problems, pecking order preferences and cultural and institutional factors. These are a potential area for future research. In this paper we focus on the borrowing power and profitability as we believe they are more directly related to individual industry characteristics.

ii It would also be interesting to study firms' capital structure decisions post-financial crisis but this is left for a future study.

iii The Debt Capacity is measured by the ratio of Tangible Fixed Assets/Total Assets on the assumption that firms with higher fixed assets as collateral find it easier to borrow money. It can be noted that this is one of a number of factors that will impact on a firm's ability to borrow.

iv Shenying Wanguo Securities found that from 1990-2012 only 77 companies had been delisted across the whole of China. See: http://blogs.wsj.com/deals/2013/03/20/delisting-in-china-existsin-name-only/. Access date: 09/10/2013.

${ }^{v}$ Not shown in Tables but available from the authors on request.

vi This hypothesis is based on Trade Off Theory. A negative sign would provide support to Pecking Order Theory.

vii Source:http://www.reuters.com/article/companyNewsAndPR/idUSPEK23112320090210 (access date: 12/11/2010).

viii This can be compared with the USA savings rate which declined from an average of $11 \%$ of national income $1960-1979$ to as little as $1 \%$ in 2005. Source: OECD National Accounts, Volume II, various years. 